\title{
Development of a Novel Submerged Membrane Bioreactor (SMBR) for Treatment of Textile Wastewater
}

\author{
Ganpat B. More*1 ${ }^{1}$, Shridhar K. Jadhav ${ }^{2}$, Sanjaykumar R. Thorat ${ }^{3}$ \\ ${ }^{1,2,3}$ School of Environmental and Earth Sciences, Kavayitri Bahinabai Chaudhari North Maharashtra University, \\ Jalgaon. \\ Email:moreganpat05@gmail.com ${ }^{1}$,shridhar.skjadhav@gmail.com²,drst118@gmail.com³
}

\begin{abstract}
The present study was conducted to investigate the performance of a commercial membrane in a pilotscale submerged membrane bioreactor (SMBR) model for the treatment of synthetic textile wastewater with reactive dye as a source of colour. The SMBR model was aerobically operated for about 3 months at continuous mode of operation at three different HRTs of 8,6 and $4 \mathrm{~h}$ with a usual permeate flux of $18 \mathrm{~L} / \mathrm{m}^{2} / \mathrm{h}$, respectively. Throughout the entire operation, an excess amount of F/M ration (0.07-0.17 g BOD/g MLSS. d), OLR (0.31-1.85 $\mathrm{kg} \mathrm{BOD}_{5} / \mathrm{m}^{3} . \mathrm{d}$ ) and declined HRT was not negatively impacted. During the overall performance of SMBR model, except conductivity, TDS and TP, a high amount of COD, $\mathrm{BOD}_{5}, \mathrm{NO}_{3}-\mathrm{N}$, TSS, Turbidity and colour removal was achieved. The average removal of COD, $\mathrm{BOD}_{5}, \mathrm{NO}_{3}-\mathrm{N}$, TSS, Turbidity and colour were $91.41 \%, 92.47 \%, 90.76$, $99.35 \%, 98.35$ and $92.66 \%$, respectively. The membrane fouling was prevented by covering a cage of wire mesh, regular backwashing and chemical cleaning to maintain constant permeate flux. The result indicated that synthetic textile wastewater can be effectively treated by the SMBR model and it has been recommended for the treatment of real textile wastewater.
\end{abstract}

Keywords: Reactive dye; submerged membrane bioreactor (SMBR); Synthetic textile wastewater; Colour; Treatment

\section{INTRODUCTION}

The reuse of water is becoming most important because, we are continuously facing shortage of water. Hence, the aim of wastewater treatment is not only to abatement of pollutants that impacts on the aquatic life but also meets to fulfill the essential water quality criteria for their reuse [1]. The textile industrial sector utilizes huge amount of water and hence it generates large water footmark in the world. Most of the water utilized in the textile industry during the process of dyeing, preparation and finishing. These processes require huge quantity of water, as of 5 to 40 times higher than the weight of fibre and resulting large amount of wastewater has been generated [2]. Designed to produce one-ton fabric, around $20-350 \mathrm{~m}^{3}$ of water has been utilized [3]. Particularly in India, about 2100 units of textile industry are running in the different states. They consume nearly $200 \mathrm{~m}^{3} / \mathrm{d}$ of water and release 1.5 million litres of effluent for each $600 \mathrm{~km}$ of fabric per day $[4,5]$.

The major pollutants in wastewater from textile industry can significantly fluctuate and are usually categorized by excessive amounts of constant substances for example, organics, dyes, toxicants, surfactants, inhibitory compounds, chlorinated compounds, salts and heavy metals, in addition to coloured dyes are the extremely challenging components of the wastewater $[6,7,8,9]$.

In the conventional textile treatment of wastewater, common practices applied are adsorption, coagulation, chemical precipitation, biological treatment, electrochemical destruction, flotation, etc. $[3,6,9,10]$. These conventional processes of treatment consume large amount of energy, manpower and chemicals, which generates chemical waste that requires further treatment [11]. In order to improve wastewater quality, options of advanced treatment have most interested in the textile wastewater treatment $[6,12,13]$. Also, many textile industries want to get better wastewater quality to meet the fresh water standards, due to rising water scarcity as well as strict legislations to save the aquatic environment [14].

To improve wastewater quality as compare to permissible standards, a more effective as well as competent technology to remove colour and organic pollutants must be recognized. Membrane bioreactor (MBR) technology is a one of the most promising technology that provides the option to get better quality of the wastewater [15]. An MBR can be demarcated as combined biological degradation process for wastewater with the help of membrane filtration $[6,16,17]$. Membrane bioreactor (MBR) is working with the conventional activated sludge process in combination with microfiltration and ultrafiltration membrane for solid separation. As compare to conventional activated sludge process, MBR has main advantages to complete solids removal, a substantial physical disinfection ability, very high amounts of carbon, nitrogen compounds and colour removal $[18,19]$. Additionally, an SMBR have capacity to free up bacteria and make permeate potential for reuse 
$[20,21,22,23,24]$. The application of SMBR technology has leads to considerable saving of energy and hence it improves the capacity of MBR technology in wastewater treatment [22,24,25].

Hence, MBR technology is an appealing choice for the wastewater treatment as well as recycle of wastewater from numerous industries such as chemical production, leather processing, automobile, dairy products, electroplating process, pharmaceuticals, and textile. The operational performance of MBR technology for treatment of textile wastewater has been studied by various researchers and their findings are discussed below.

Garcia et al. studied treatment of textile wastewater with combination of submerged membrane bioreactor [26]. The investigation study has been conducted by using two different hydrophobic and hydrophilic coated polytetrafluoroethylene (PTFE) membranes having feed temperature of $60{ }^{\circ} \mathrm{C}$ and permeate temperature of $45{ }^{0} \mathrm{C}$. this study was aimed to compare typical hydrophobic PTFE membranes with hydrophilic coated polytetrafluoroethylene (PTFE) Membranes. The typical hydrophobic PTFE membrane shows maximum salts rejection rate about $99 \%$. Although, the high amount of EC was observed because of the gradual wetting of the membrane. On the other hand, the coated PTFE membrane shows highest resistance for the wetting of membrane.

Huang et al. studied submerged hollow fibre MBR having capacity of $400 \mathrm{~L} /$ day for treating dye containing wastewater about 100 days [27]. A PVDF membrane having pore size $0.2 \mu \mathrm{m}$ has been utilized to removal of dyes and other organic pollutants. The membrane flux and transmembrane pressure was maintained between $2-8 \mathrm{~L} / \mathrm{m}^{2}$ and 5 and $10 \mathrm{kPa}$. The feed concentration of COD, BOD, $\mathrm{NH}^{3}-\mathrm{N}, \mathrm{pH}$ and colour has found to be $600-1200 \mathrm{mg} / \mathrm{L}, 90-170 \mathrm{mg} / \mathrm{L}$, 10-23 mg/L, 10-14 and 250-400 colour units, respectively. The operational conditions of HRTs were studied at 6 to $22.5 \mathrm{~h}$. The results from this investigation shows that the scheme achieved maximum performance at the level of 80 to $90 \%$ efficiency. The removal of $\mathrm{COD}, \mathrm{NH}^{3}-\mathrm{N}$ and colour was found to be $90 \%, 90-95 \%$ and $60-75 \%$ respectively. However, the colour removal percent could not meet the standards and it needs further treatment.

You and Teng tested a laboratory scale anaerobic sequential batch reactor (SBR) with combination of aerobic membrane bioreactor (aerobic MBR) aimed to treatment of textile wastewater encompassing Reactive black 5 and azo dye removal [28]. They noted that the feed and permeate concentration of COD was 310.6 and $2.3 \mathrm{mg} / \mathrm{L}$, respectively. Nearly $97.5 \%$ of COD removal and $9.1 \%$ of true colour removal efficiency was achieved by using the anaerobic SBR and the aerobic MBR respectively. The isolated bacteria subspecies Lactococcus lactis and Lactobacillus casei has degraded each more than $99 \%$ of Reactive black 5 within time of $5.5 \mathrm{~h}$ and $36 \mathrm{~h}$ respectively.

Yigit et al. examined the performance of a submerged membrane bioreactor for the treatment of wastewater from denim textile factory having influent values of colour, conductivity and TDS were $286-8100 \mathrm{Pt}-\mathrm{Co}$, $1578-9440 \mu \mathrm{S} / \mathrm{cm}$ and $789-4720 \mathrm{mg} / \mathrm{L}$ respectively [13]. The hollow fibre membrane having nominal pore size of $0.04 \mu \mathrm{m}$ were utilized with two different phases first one was MBR sludge was not wasted and second one was SRT was maintained at 25 days. The permeate flux in both phases was maintained at $20 \mathrm{~L} / \mathrm{m}^{2} \mathrm{~h}$ and the plant was worked continuously at HRT $14 \mathrm{~h}$ and MLSS at 13.9 to $17.0 \mathrm{~g} / \mathrm{L}$ with backwashing time of $15 \mathrm{~s}$ per time period of each $10 \mathrm{~min}$. having flow rate of 600 $\mathrm{mL} / \mathrm{min}$. The findings indicate that the MBR system shows excellent performance having removal of TSS and colour (99\%), BOD/ COD (97\%), moderate performance in the removal of TP, $\mathrm{NH}_{3}-\mathrm{N}, \mathrm{NO}_{2}-\mathrm{N}, \mathrm{TN}$, $\mathrm{TKN}, \mathrm{NO}_{3}-\mathrm{N}(60-90 \%)$ and poor performance in the removal of Conductivity and TDS (4\%) respectively. However, the findings revealed that the phase second with SRT of 25 days has performed better that the phase first.

Bouhadjar et al. tested a pilot scale side-stream and submerged membrane bioreactor for model textile wastewater treatment [1]. The HRT was maintained at different $20 \mathrm{~L} / 0.00856 \mathrm{~m}^{2}$ and $57 \mathrm{~L} / 0.33 \mathrm{~m}^{2}$ for sidestream and submerged MBR because of the capacities of reactors and surface of the membrane module. The values of influent parameters were $\mathrm{pH}(7.5 \pm 0.5)$, COD $(2,367 \pm 125 \mathrm{mg} / \mathrm{L}), \mathrm{BOD}_{5}(731 \pm 80 \mathrm{mg} / \mathrm{L})$, Total-N $(78 \pm 8 \mathrm{mg} / \mathrm{L})$ and Conductivity $(6.6 \pm 0.15 \mathrm{mS} / \mathrm{cm})$ respectively. They noted that the performance of removal COD varied between 90 and $97 \%$, colour rejection was $20-40 \%$ for red dye and $50-90 \%$ for blue dye in both units. However, in addition to improve the quality of wastewater, a nanofiltration membrane needs to test in the SSMBR model and to be tested on the SMBR model.

The literature review showed that the performance of MBR technology in textile industry has suffers with a common problem of fouling [29]. Hence, membrane fouling is an interference between the progress of the MBR technology predominantly when it losses flux that restoration of cleaning has not done [29]. Similarly, the advanced MBR cannot fulfill standards while treatment of textile effluents in the presence of high colour. The excellent performance can be attributed, when the low molecular weight of dyes can be treated with the MF and UF membranes.

Taking into consideration of fouling problem, an effort is prepared in this study to decrease fouling by using cage of wire mesh with regular backwashing. The main objective of this work was to obtain optimal conditions for performance of submerged membrane reactors at pilot scale. The ultrafiltration hollow fibre 


\section{E-ISSN: 2321-9637}

\section{Available online at www.ijrat.org}

(UF-HF: poly(vinylidene fluoride) (PVDF) membrane utilize to treatment of textile effluent under different organic loading rates (OLRs) and hydraulic retention time (HRTs) for continuous removal of colour, conductivity, $\mathrm{COD}, \mathrm{BOD}, \mathrm{NO}_{3}-\mathrm{N}$, TSS, turbidity and TP. This study may help to provide preliminary step for the application of MBR technology for textile effluent, while this work has not studied in detail so far. In addition, this study may offer appropriate perception towards the treatment of textile effluent.

\section{METHODOLOGY}

\subsection{Reactive dye}

The blue antraquinone reactive dye chosen for this study was Remazol Brilliant Blue R. collected from Jinendra Scientifics, Jalgaon, India. This dye has a typical industrial application and it has been widely used in textile industry. The chemical compositions of the Remazol Brilliant Blue $\mathrm{R}$ dye are presented in Table 1, Fig 1.<smiles>Nc1c(S(=O)(=O)O[AlH2])cc(Nc2cccc(S(=O)(=O)CCOS(=O)(=O)O[AlH2])c2)c2c1C(=O)c1ccccc1C2=O</smiles>

Fig 1. Structure of Remazol Brilliant Blue R.

Table 1. Characteristics of Remazol Brilliant Blue R.

\begin{tabular}{lc}
\hline Characteristics & Remazol Brilliant Blue R. \\
\hline $\begin{array}{l}\text { Maximum absorbance } \\
\text { wavelength }\end{array}$ & 595 \\
$\begin{array}{l}\text { Molecular weight } \\
\text { g/mol) }\end{array}$ & 626.5 \\
Empirical formula & $\mathrm{C}_{22} \mathrm{H}_{16} \mathrm{~N}_{2} \mathrm{Na}_{2} \mathrm{O}_{11} \mathrm{~S}_{3}$ \\
\hline
\end{tabular}

\subsection{Activated bio-sludge}

Activated bio-sludge was collected from activated sludge bed at M/s. SMS WALUJ CETP Private Limited, Aurangabad and utilized as a microbial media in SMBR pilot model. To development of wide microbial population, the bio-sludge has acclimatized for 5 days in a laboratory. The overall composition of the bio-sludge had MLSS and MLVSS in the range of $12,264-13,675$ and 7,154-7,985 $\mathrm{mg} / \mathrm{L}$ respectively.

\subsection{Textile wastewater sample}

The overall laboratory experiment was carried out by using synthetic wastewater, because composition of real textile wastewater has an inconstant concentration of physicochemical parameters, which was very difficult to control (Table 2). The synthetic textile wastewater sample was prepared by using [30] method. As per Deowan et al. method glucose has been added as carbon source, urea has been added as nitrogen source, and $\mathrm{K}_{2} \mathrm{HPO}_{4}$ and $\mathrm{KH}_{2} \mathrm{PO}_{4}$ has been added as orthophosphate phosphorus $\left(\mathrm{PO}_{4}{ }^{3-}\right)$ source in the synthetic textile wastewater. The $\mathrm{pH}$ level was maintained neutral with the addition of sodium bicarbonate $\left(\mathrm{NaHCO}_{3}\right)$. The characteristics of prepared synthetic textile wastewater has summarized in Table 2.

Table 2. Characteristics of synthetic textile wastewater sample

\begin{tabular}{lc}
\hline Parameters & $\begin{array}{c}\text { Average measured values } \\
\text { (min.-max.) }\end{array}$ \\
\hline $\mathrm{BOD}_{5}(\mathrm{mg} / \mathrm{L})$ & $472(410-530)$ \\
$\mathrm{COD}(\mathrm{mg} / \mathrm{L})$ & $1060(891-1289)$ \\
$\mathrm{NO}_{3}-\mathrm{N}(\mathrm{mg} / \mathrm{L})$ & $48(38-58)$ \\
$\mathrm{TP}(\mathrm{mg} / \mathrm{L})$ & $11(7-16)$ \\
$\mathrm{TDS}(\mathrm{mg} / \mathrm{L})$ & $2163(1264-2489)$ \\
$\mathrm{TSS}(\mathrm{mg} / \mathrm{L})$ & $126(98-142)$ \\
Turbidity $(\mathrm{NTU})$ & $284(239-331)$ \\
Conductivity $(\mathrm{mS} / \mathrm{cm})$ & $6.27(2.97-8.64)$ \\
Colour $(\mathrm{mg} / \mathrm{L})$ & $96(81-120)$ \\
\hline
\end{tabular}

\subsection{Physico-chemical analysis}

Analysis of mixed liquor suspended solids (MLSS), mixed liquor volatile suspended solids (MLVSS), dissolved oxygen (DO), chemical oxygen demand (COD), biochemical oxygen demand $\left(\mathrm{BOD}_{5}\right)$, nitrate-nitrogen $\left(\mathrm{NO}_{3}-\mathrm{N}\right)$, total phosphorous (TP), total dissolved solids (TDS), total suspended solids (TSS), Turbidity and colour were measured by using standard methods of APHA [31]. Turbidity was measured by using Turbidity meter (HACH 2100Q). A pH meter (Elico LI614) was used for determines $\mathrm{pH}$. The colour was measured by using UV-Visible spectrophotometer (Elico SL159) at the peak wavelength of $595 \mathrm{~nm}$. The concentration of dye was calculated from Beer's law as absorbance vs concentration. Decolourization efficiency was calculated using concentration values of permeate and feed.

\subsection{Selection of membrane}

The objectives of this study were to evaluate the performance of submerged membrane bioreactor (SMBR). Hence, a UF-HF poly(vinylidene fluoride) (PVDF) membrane obtained from Aquaplus Water Purifiers Pvt. Ltd, Pune, India has been selected for the textile wastewater treatment. The characteristics of UFHF poly(vinylidene fluoride) (PVDF) membrane used in the present study are presented in Table $\mathbf{3}$. 


\section{International Journal of Research in Advent Technology, Vol.7, No.4, April 2019 E-ISSN: 2321-9637 \\ Available online at $w w w . i j r a t . o r g$}

Table 3. Characteristics of selected membrane

\begin{tabular}{lc}
\hline Technical data & Values \\
\hline Membrane & Poly (vinylidene fluoride) \\
material & (PVDF) \\
Geometry & Hollow fibre \\
Filtration & Ultrafiltration \\
Outer diameter & $1.80 \mathrm{~mm}$ \\
Inner diameter & $0.90 \mathrm{~mm}$ \\
Pore size & $0.01 \mu \mathrm{m}$ \\
Surface area & $0.038 \mathrm{~m}^{2}$ \\
\hline
\end{tabular}

\subsection{Characterization of membrane}

\subsubsection{Scanning Electron Microscope}

Cross section and outer surface morphology of the PVDF hollow fibre membrane was studied by using field emission scanning electron microscope (FESEM) (Model: S-4800, Hitachi, Japan). Before analysis of right side of the tank. Mechanical stirrer was used to uniform mixing of the influent with activated sludge. A bioreactor was placed at middle of the influent and permeate tank. An air diffuser having flow rate of about 6-8 L/min was attached at the bottom of membrane module and air was supplied with an air blower pump with a nominal flow rate of $3 \mathrm{~L} / \mathrm{min}$ to increase the oxygen level in the bioreactor as well as to decrease the fouling problems with the membrane surface. In the bioreactor, the membrane was placed around with stainless steel wire cage having pore size of $100 \mu$ to reject the sticky material. A suction pump was utilized to drain out the effluent from bioreactor through a membrane module at the 10 min continuous flow and 30 seconds for backwashing. A transmembrane pressure (TMP) was continuous monitored by using a vacuum gauge and permeate flow was measured with the help of rotameter. The permeate was stored in

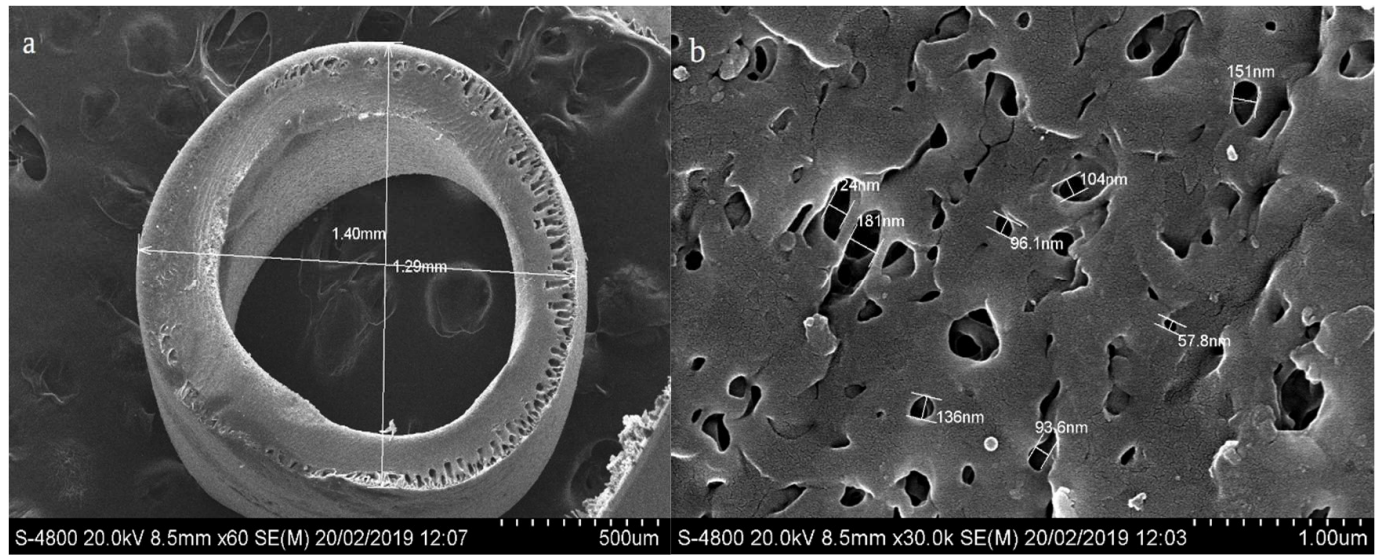

Fig 2. FESEM images of PVDF hollow fibre membrane a) Cross section b) Outer surface

morphology, the hollow fibre membrane was immersed in liquid nitrogen for duration of $5 \mathrm{~min}$ to obtain perfect cut of cross section piece. The Cross section and outer surface pieces were placed on to the two-sided carbon tape and then the hollow fibre membrane were coated with gold using an ion sputter (Model: E1010, Hitachi, Japan). The morphological properties of a PVDF hollow fibre membrane were shown in Fig 2.

\subsection{Submerged Membrane Bioreactor}

An submerged membrane bioreactor (SMBR) pilot plant with UF-HF poly(vinylidene fluoride) (PVDF) membrane submerged in the bioreactor having active volume of $75 \mathrm{~L}$ was used in present study. A schematic diagram of SMBR module is shown in Fig 3. The SMBR module contains three compartments having each $6.34 \mathrm{~m}^{2}$ of area and having total area of $19.03 \mathrm{~m}^{2}$. From left, first compartment is neutralization/influent tank, which equipped with a mechanical stirrer and a feed pump with flow meter was also attached to the permeate tank and it was also used for the backwashing. A level sensor was attached for all tanks to maintain the constant working time and HRT. All the parameters were continuous monitored and the data was recorded for the performance evaluation.

\subsection{Operational Conditions}

The pilot scale SMBR system was aerobically operated continuously at about 3 months with different HRT of 08, 06 and $04 \mathrm{~h}$ respectively. The capacity of SMBR system was $240-310 \mathrm{~L} /$ day with an average constant flux rate of $18 \mathrm{~L} / \mathrm{m}^{2} / \mathrm{h}$. The COD and food/microorganisms $(\mathrm{F} / \mathrm{M})$ ratio were maintained at 891-1289 mg/L and 0.09 to $0.17 \mathrm{~g} \mathrm{BOD} / \mathrm{g}$ MLSS/d for estimation of effluent quality at steady operation. The MLSS and MLVSS concentrations was in the range of 12,264-13,675 and 7,154-7,985 mg/L. Table 4 shows the working parameters of SMBR system. A regular backwashing was applied at 30 seconds each after 10 min permeate flow. The solid retention time was countless throughout the entire operation period since 


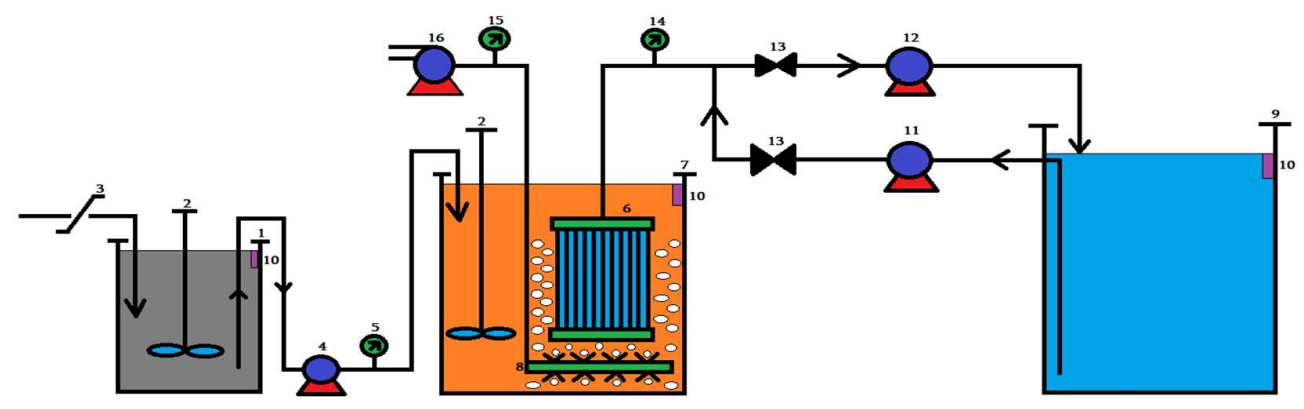

Fig. 3. Schematic diagram of sMBR model. 1. Influent/equalization tank 2. Stirrer 3. Screening 4. Feed pump 5. Flow meter 6. Membrane module 7. MBR tank 8. Air diffusers 9. Permeate tank 10. Level controller 11. Backflush pump 12. Suction pump 13. Solenoid valve 14. Pressure meter 15. Air flow meter 16. Air pump.

there was no ejection of biomass. The SMBR operational and physicochemical parameters including $\mathrm{F} / \mathrm{M}$ ratio, transmembrane pressure (TMP) organic loading rate (OLR), mixed liquor suspended solids (MLSS), mixed liquor volatile suspended solids (MLVSS), dissolved oxygen (DO), chemical oxygen demand (COD), biochemical oxygen demand $\left(\mathrm{BOD}_{5}\right)$, nitrate-nitrogen $\left(\mathrm{NO}_{3}-\mathrm{N}\right)$, total phosphorous (TP), total dissolved solids (TDS), total suspended solids (TSS), Turbidity and colour were continuously measured during every run. average COD removal was $94.23 \%, 91.46 \%$ and $88.54 \%$ respectively. Simultaneously, the average $\mathrm{BOD}_{5}$ removal at $08.00,06.00,04.00 \mathrm{~h}$ of HRTs was $94.06 \%, 92.05 \%$ and $91.31 \%$ respectively. Similarly, Pradip Saha et al. reported high COD and BOD removal at about $90 \%$ and $80 \%$ during the treatment of textile wastewater in Bangladesh [32]. This is reveals that, the organic pollutants in the textile wastewater were approximately removed by the SMBR system. As compare to HRTs 06.00 and $04.00 \mathrm{~h}$, the HRT 08.00 has achieved maximum removals. This is the

Table 4. Operational conditions of sMBR system

\begin{tabular}{lccc} 
& & HRT, & \\
\cline { 2 - 4 } Parameters & 08.00 & 06.00 & 04.00 \\
\hline Days & $1-30$ & $31-60$ & $61-90$ \\
TMP (psi) & $2.1-2.7$ & $2.5-3.7$ & $2.7-4$ \\
Permeate flux (L/m $\left.{ }^{2} \mathrm{~h}\right)$ & $18-23.1$ & $15.8-23$ & $13.7-19.3$ \\
F/M ratio (g BOD/g MLSS d) & $0.07-0.15$ & $0.07-0.17$ & $0.07-0.15$ \\
MLSS (mg/L) & 8469 & 9610 & 11057 \\
OLR (kg BOD $\left./ \mathrm{m}^{3} . \mathrm{d}\right)$ & $0.31-0.69$ & $0.56-1.21$ & $0.91-1.85$ \\
BOD influent $(\mathrm{mg} / \mathrm{L})$ & $410-512$ & $412-530$ & $438-518$ \\
\hline
\end{tabular}

\section{RESULTS AND DISCUSSION}

The influent and permeate values of measured parameters are illustrated in Table 5. Except the TDS, total phosphorous (TP) and conductivity, the chemical oxygen demand (COD), biochemical oxygen demand $\left(\mathrm{BOD}_{5}\right)$, nitrate-nitrogen $\left(\mathrm{NO}_{3}-\mathrm{N}\right)$, total suspended solids (TSS), Turbidity and colour removals were obtained in very high amounts. The organic pollutants $\mathrm{COD}$ and $\mathrm{BOD}_{5}$ percent removal and measured values of influent and effluent are demonstrated in Fig 4 and 5. During the HRTs at $08.00,06.00,04.00 \mathrm{~h}$, the advantages of MBR system as compare to the conventional activated sludge process [33].

The F/M ratio values were falls in the range of 0.07 $0.15,0.07-0.17$ and $0.07-0.15 \mathrm{~g} \mathrm{BOD} / \mathrm{g}$ MLSS d during the HRTs of $08.00,06.00,04.00 \mathrm{~h}$, respectively. It is because of the higher MLSS in the SMBR bioreactor. Generally, in the conventional activated sludge system the $\mathrm{F} / \mathrm{M}$ ratio varies between $0.05-1.5 / \mathrm{d}$ but in the MBR system it is $<0.1 / \mathrm{d}$ [6]. The food accessibility in the MBR for the growth of microorganisms is a most important aspect. Restricted food availability is mostly 


\section{Available online at www.ijrat.org}

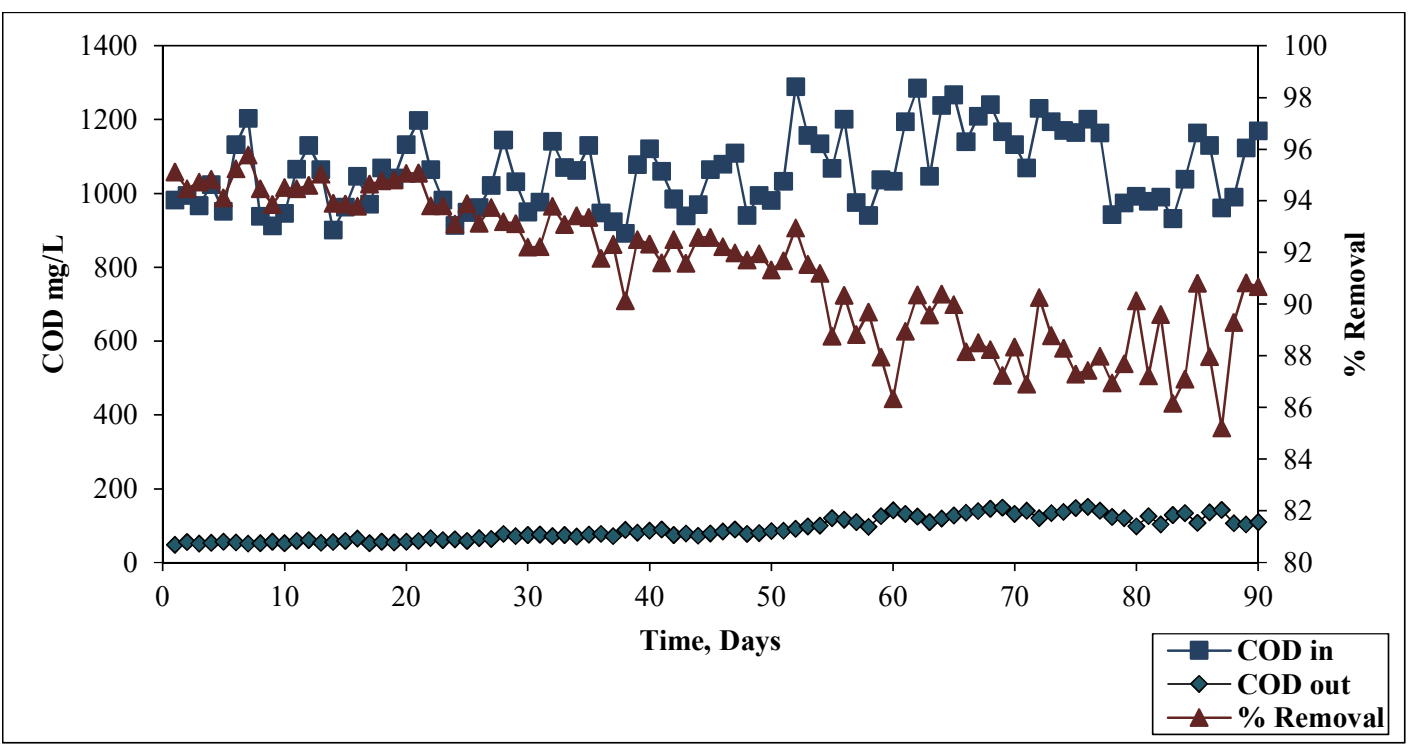

Fig 4. showing percent removal of COD and measured values of Influent and effluent during entire operation

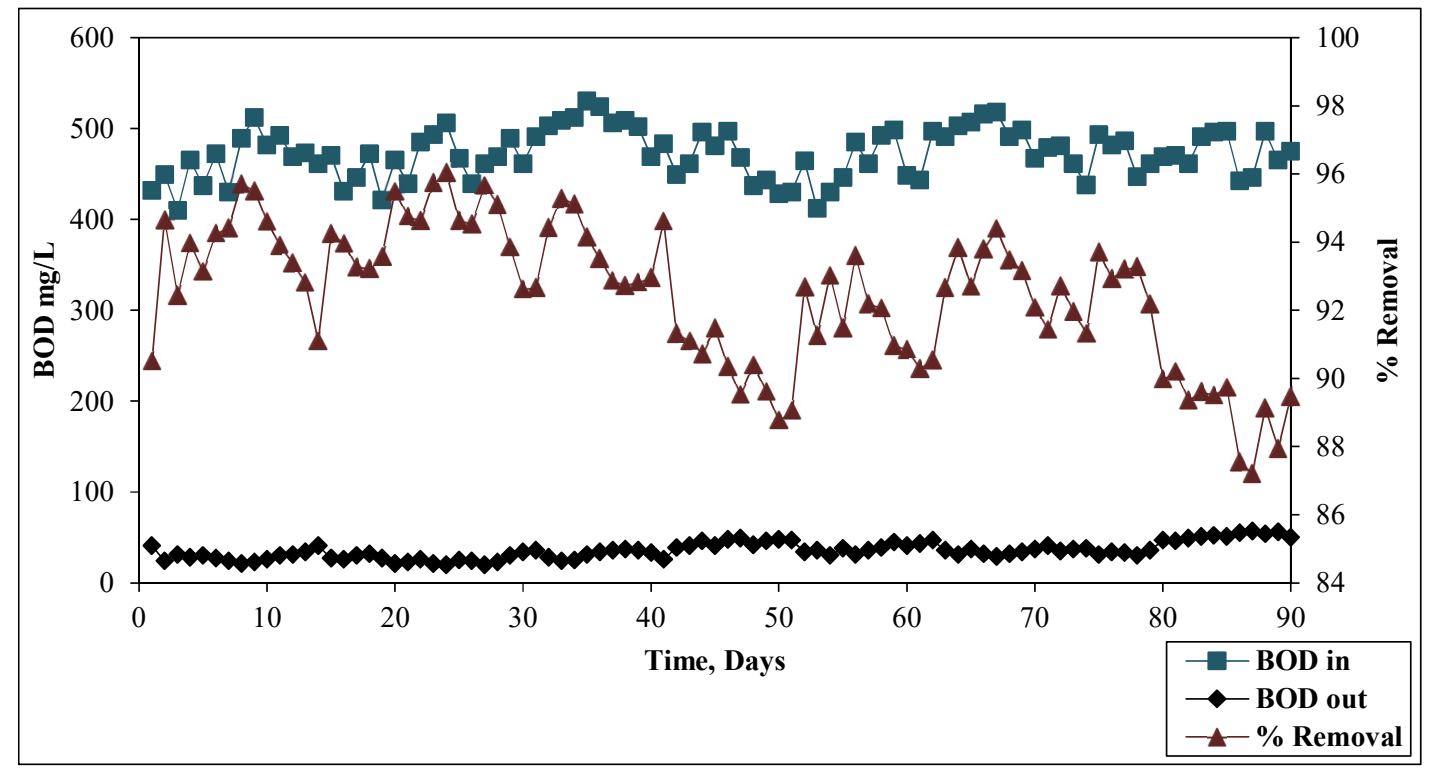

Fig 5. showing percent removal of $\mathrm{BOD}_{5}$ and measured values of Influent and effluent during entire operation

reliant on the biomass and food accessibility in the bioreactor. Hence, for the measured values of BOD in the wastewater, when the provided $\mathrm{F} / \mathrm{M}$ ratio is become low and number of microorganisms becomes high, then it achieves highest removal of BOD [34]. In our study, the organic compounds were completely oxidized at presented F/M ratio and OLRs. Fig 6 shows the high variations between $\mathrm{F} / \mathrm{M}$ ratio and $\mathrm{BOD}$ removal.

Fig 7 shows the variations of OLR and COD removal throughout the operation. The results showed that the removal of COD was not affected by the variations in the OLR. Similarly, F. Sun et al. also reported that the OLR is not effect on the removal performance of organic pollutants [35]. In our study, the OLR values throughout operation were in the range of $0.31-0.69,0.56-1.21$ and $0.91-1.85 \mathrm{~kg} \mathrm{BOD} / \mathrm{m}^{3}$. $\mathrm{d}$ at HRTs of $08.00,06.00,04.00 \mathrm{~h}$, respectively.

The percent removal $\mathrm{NO}_{3}-\mathrm{N}$ and concentration values of influent and permeate throughout whole operation of SMBR model are illustrated in Fig 8. The complete removal of $\mathrm{NO}_{3}-\mathrm{N}$ ions was achieved by using banana stem biochar as biomass for adsorption of $\mathrm{NO}_{3}-\mathrm{N}$ ions. The biochar was prepared from slow pyrolysis at $450{ }^{\circ} \mathrm{C}$ and a dose of $2 \mathrm{~g} / \mathrm{L}$ was mixed in 


\section{Available online at www.ijrat.org}

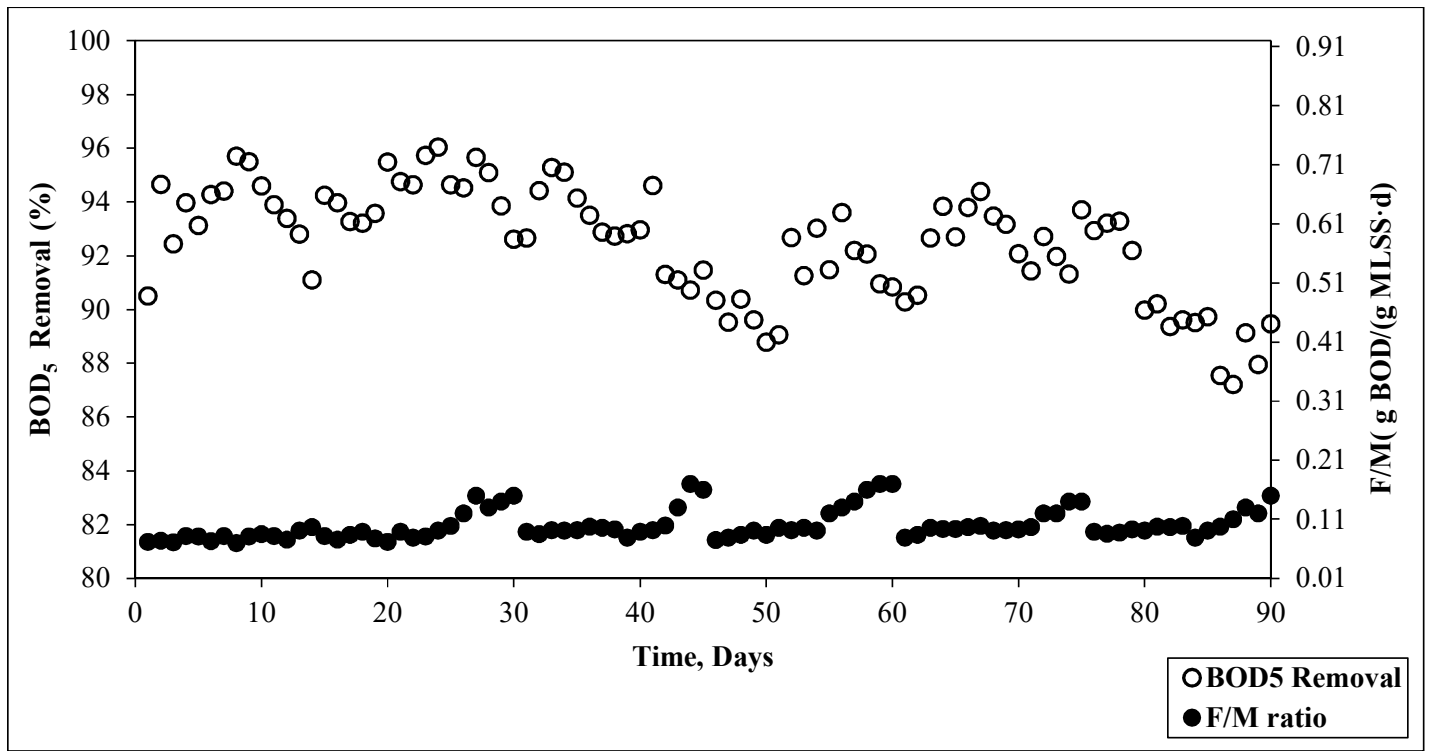

Fig 6. showing variations of $\mathrm{F} / \mathrm{M}$ ratio and BOD removal during entire operation

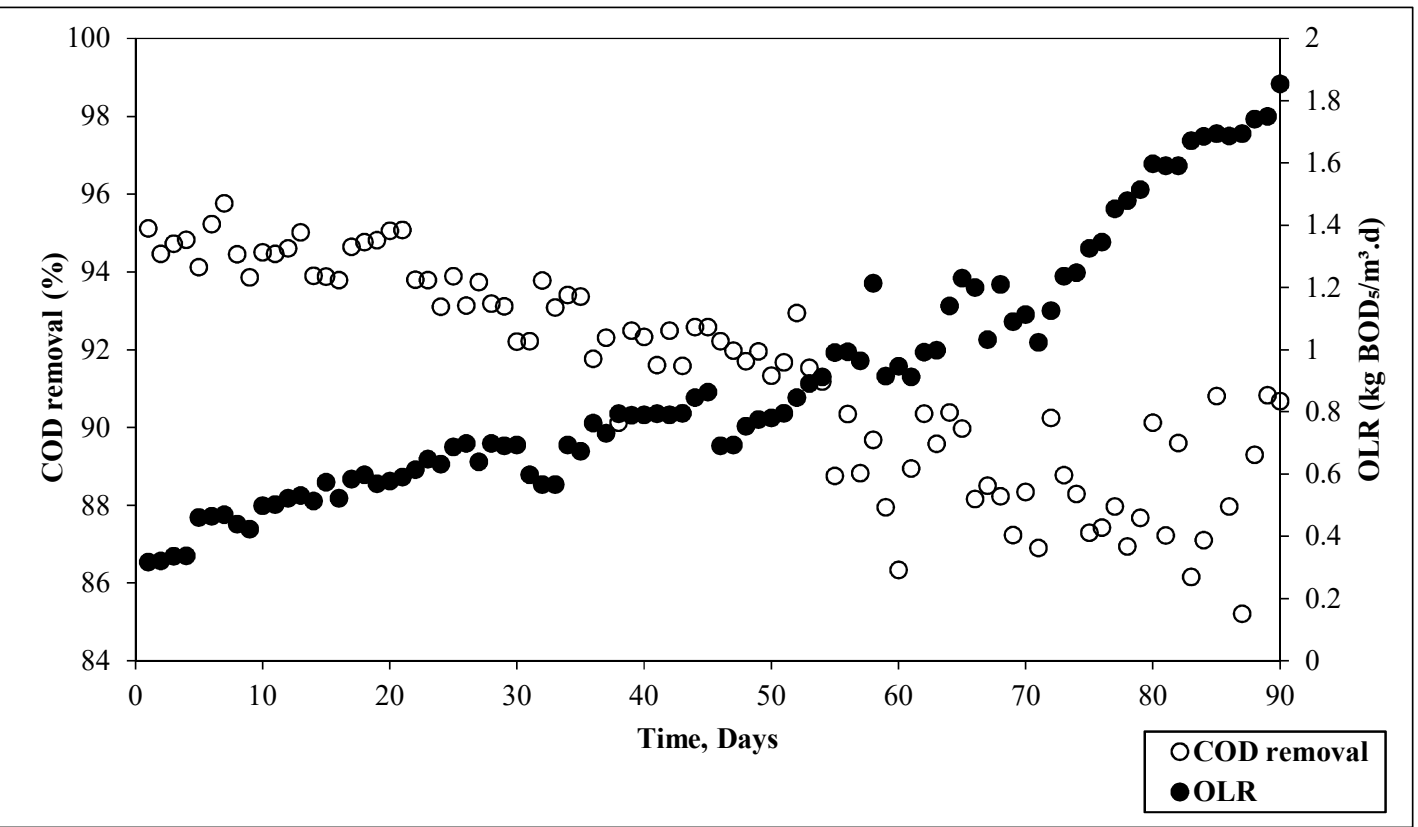

Fig 7. showing variations of OLR and COD removal during entire operation

the bioreactor chamber. The average concentration of $\mathrm{NO}_{3}-\mathrm{N}$ in the permeate was about $4.5 \mathrm{mg} / \mathrm{L}$. The results obtained from MBR model with addition of biochar as a biomass showed that, the average adsorption and separation of $\mathrm{NO}_{3}-\mathrm{N}$ ions at HRTs of $08.00,06.00$, $04.00 \mathrm{~h}$ were $92.05 \%, 91.59 \%$ and $88.65 \%$, respectively. Similarly, Awadalla et al. reported high amounts of $\mathrm{NO}_{3}-\mathrm{N}$ removal $(91.1 \%)$ from mine effluent by using membrane technology [36].

The TSS removal were obtained in very high amount $(>99 \%)$ during the whole operation of MBR model. The average permeates values of TSS throughout the operation were in the range of 0.1-1.6 mg/L. Fig 9 shows variations of TSS during the whole operation period. Furthermore, the TSS removal was not influenced by the operational conditions of the MBR model. In the same way, the removal of turbidity was also achieved in high amounts (Fig 10). The average maximum turbidity removal values during HRTs of $08.00,06.00,04.00 \mathrm{~h}$ were $99.44 \%, 99.37 \%$ and $99.23 \%$, respectively. The average permeate concentration of turbidity during overall operation was 


\section{Available online at www.ijrat.org}

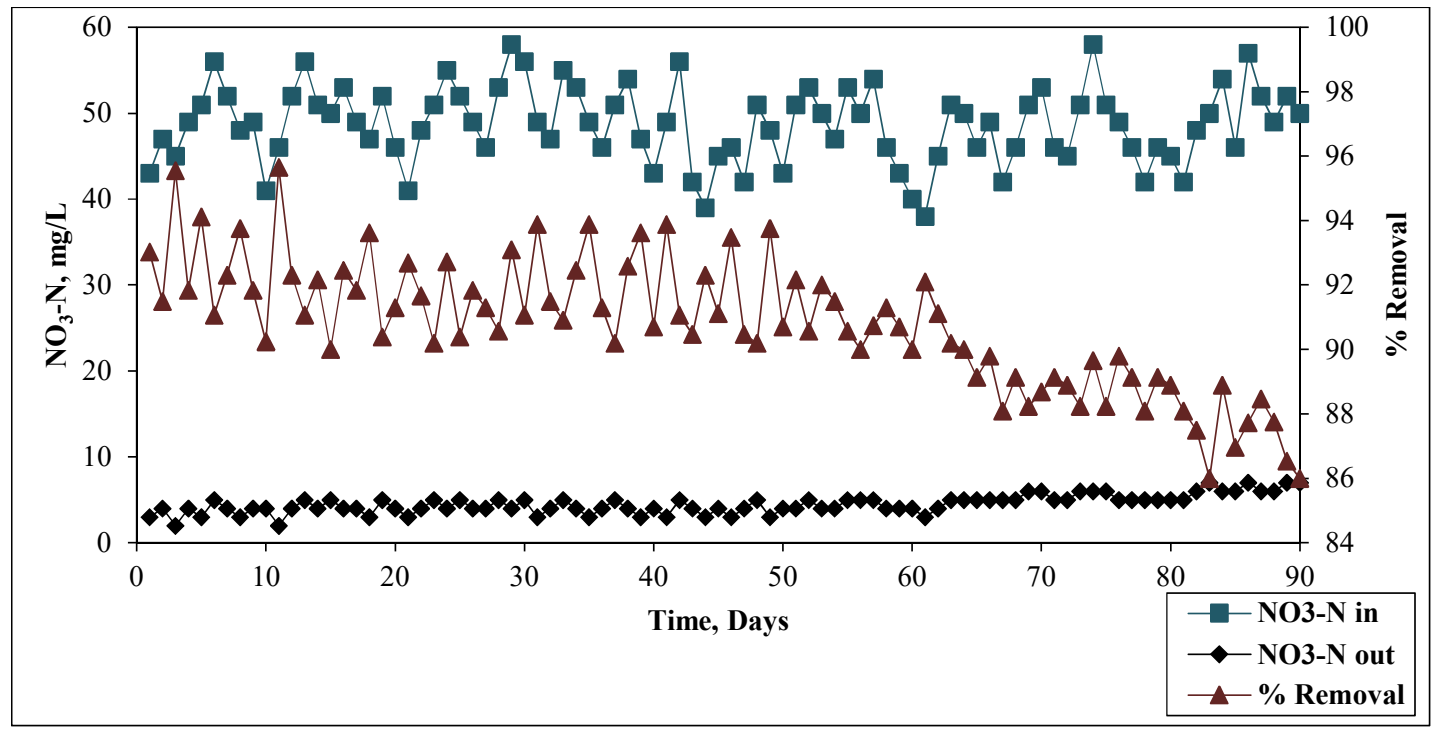

Fig 8. showing percent removal of $\mathrm{NO}_{3}-\mathrm{N}$ and measured values of influent and effluent during entire operation

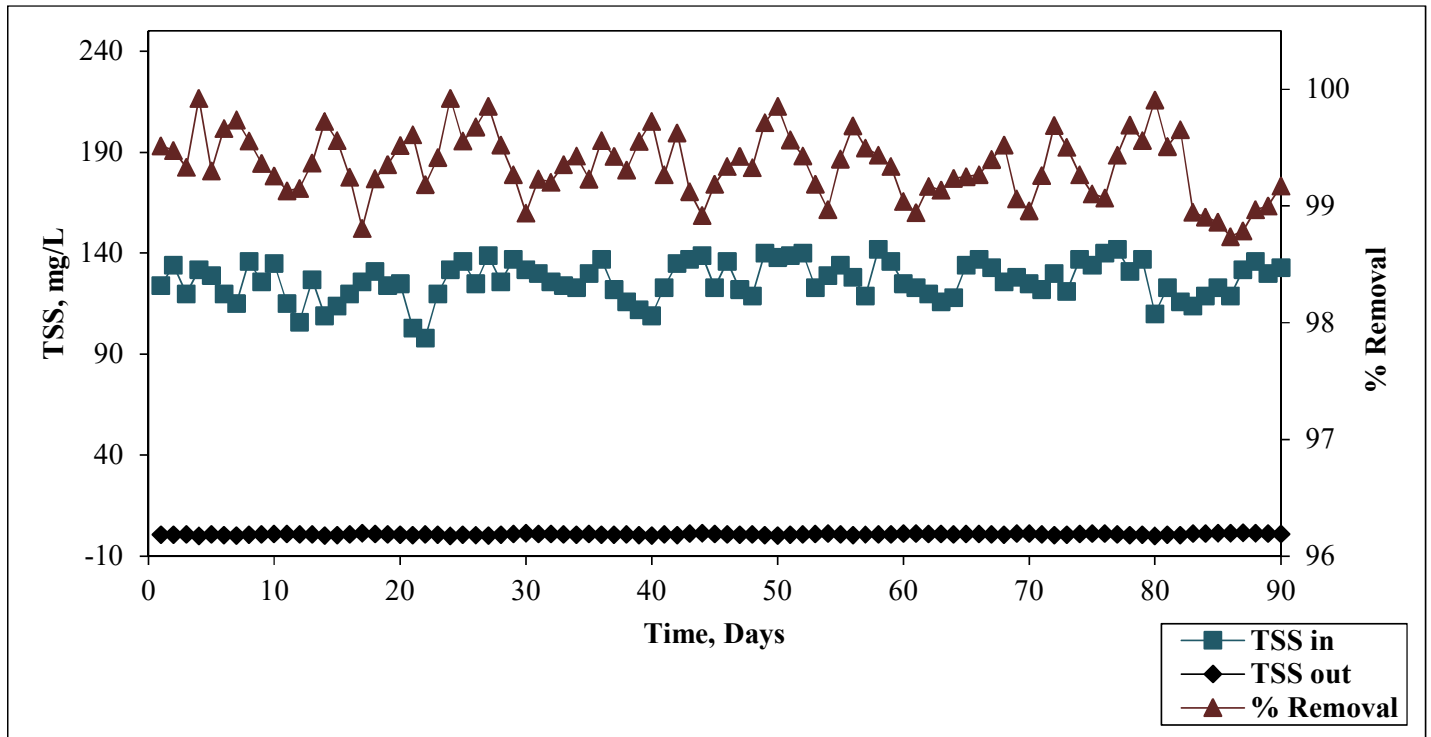

Fig 9. showing percent removal of TSS and measured values of influent and effluent during entire operation

found to be $>1.6$ NTU. The results obtained from overall operation has indicated that, the MBR model has major advantage to removes high amounts of particulate matters as well as organic compounds.

The colour is a physicochemical parameter which gives important evidence related to the quality of the water and it can be easily determined. The permeate and influent concentrations of colour throughout entire operation were showed in Fig 11. An average colour removal at HRTs of $08.00,06.00,04.00 \mathrm{~h}$ were $94.89 \%$, $94.28 \%$ and $88.80 \%$, respectively. The HRT $08.00 \mathrm{~h}$ was removes maximum colour than the $06.00,04.00 \mathrm{~h}$ of HRTs. The concentration of colour in the influent (100 $\mathrm{mg} / \mathrm{L})$ was completely removed in the MBR model. It is concluded that, the ultrafiltration membrane retains microorganisms, which are degrade the colour compounds present in the textile wastewater. Another, the main mechanism of colour removal was an addition of biochar in to the bioreactor, which results in to the maximum adsorption of colour. Similarly, Y. Zheng et al. was reported textile wastewater treatment by using biological submerged hollow fiber nanofiltration membrane, which was achieved $99.3 \%$ of colour removal [37].

During the entire operation, the permeate flux was set to $18 \mathrm{~L} / \mathrm{m}^{2} / \mathrm{h}$. An average permeate flux at HRTs of $08.00,06.00,04.00 \mathrm{~h}$ were $18,15.8$ and $13.7 \mathrm{~L} / \mathrm{m}^{2} / \mathrm{h}$, respectively. Correspondingly, the TMP during overall 


\section{Available online at www.ijrat.org}

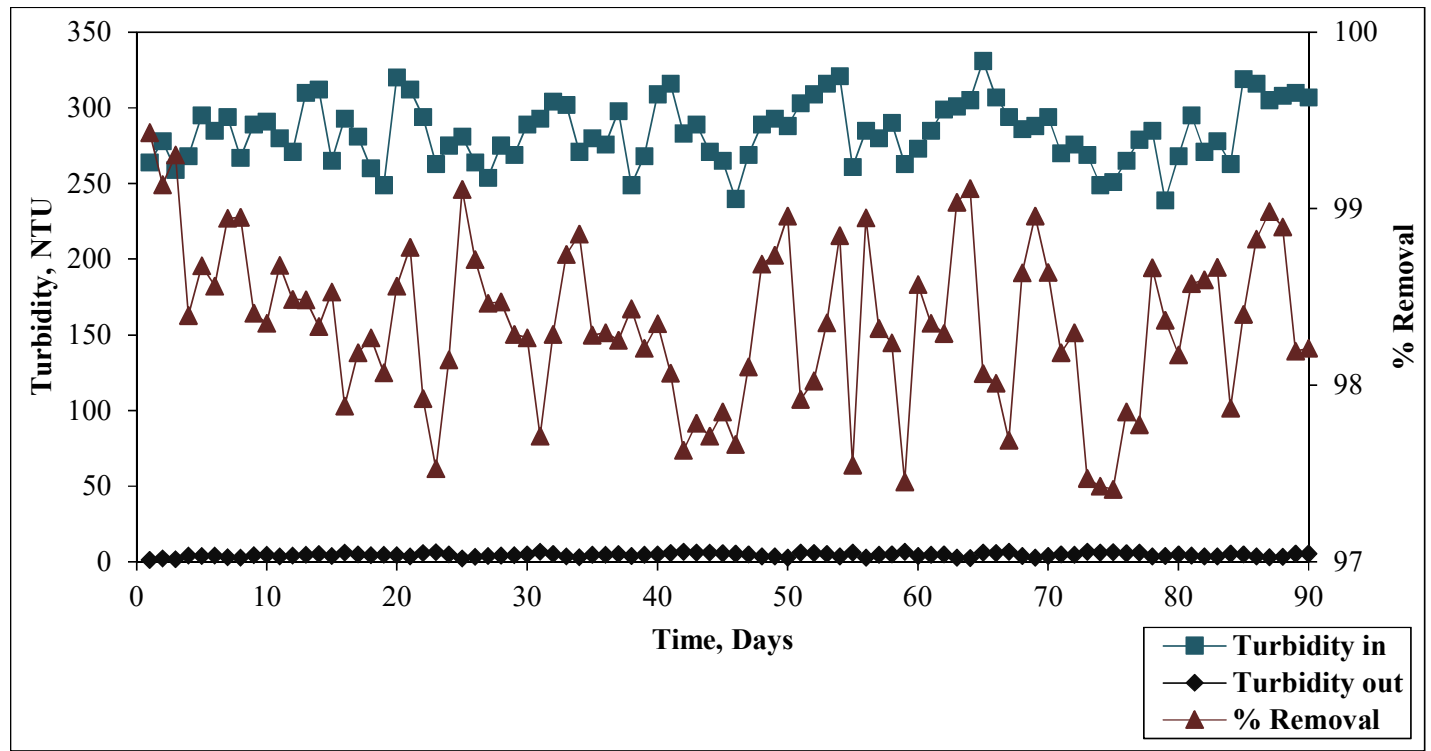

Fig 10. showing percent removal of Turbidity and measured values of influent and effluent during entire operation

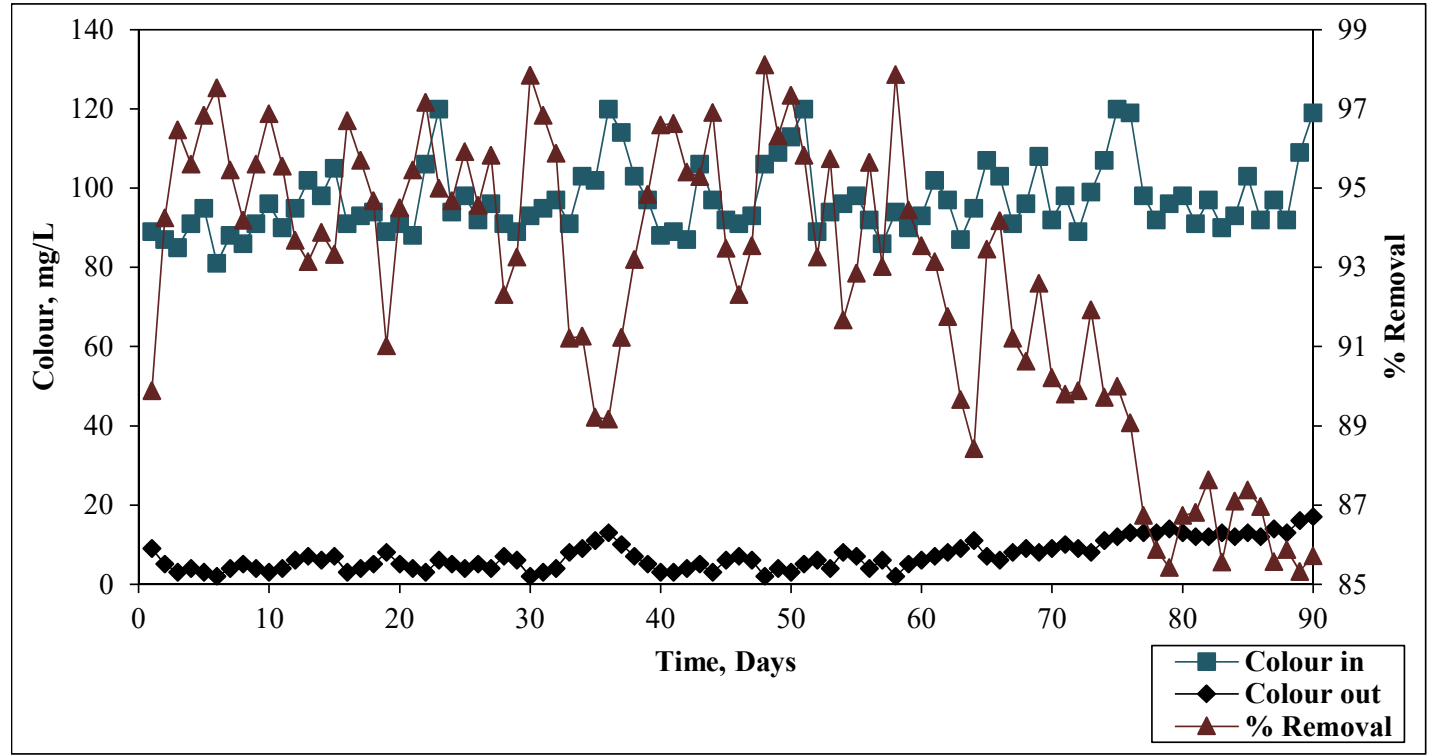

Fig 11. showing percent removal of colour and measured values of influent and effluent during entire operation

operation period were in the range of 2.1-4 psi, respectively. The membrane was moderately fouled because of sticky material deposit on to the surface of membrane, but due to covering of wire mesh as well as continuous backwash of 30 seconds of each $10 \mathrm{~min}$ permeate flow it was prevents from severe fouling. At the interval of every fifteen days, an ex situ chemical cleaning was done with a soaking of membrane with citric acid and sodium hypochlorite for about $5 \mathrm{~h}$. After each cleaning of membrane, the TMP was decreased up to 2.3 psi and permeate flux was reached up to 22
$\mathrm{L} / \mathrm{m}^{2} / \mathrm{h}$. It has been concluded that, the regular chemical cleaning increases permeability of membrane.

\section{CONCLUSION}

During the treatment of synthetic textile wastewater by using SMBR model, except conductivity, TDS and $\mathrm{TP}$, an outstanding result were achieved for the different physicochemical parameters. The excess amount of OLR, F/M ratio and MLSS was not severely effect on to the performance of SMBR model. Despite the $04.00 \mathrm{~h}$ HRT, the removal of COD, $\mathrm{BOD}_{5}, \mathrm{NO}_{3}-\mathrm{N}$, 


\section{International Journal of Research in Advent Technology, Vol.7, No.4, April 2019 E-ISSN: 2321-9637 \\ Available online at www.ijrat.org}

TSS, Turbidity and colour were obtained more than $90 \%$, respectively. The outcome of this study reveals that, the HRT of $08.00 \mathrm{~h}$ was best for the treatment of synthetic textile wastewater. The combination of biochar with high amounts of MLSS were obtained a significant denitrification and removes maximum 95\% of $\mathrm{NO}_{3}-\mathrm{N}$ and $98 \%$ of colour. The continuous backwashing and utilization of cage of wire mesh has significantly prevents membrane from fouling and resulted average permeate flux of $18 \mathrm{~L} / \mathrm{m}^{2} / \mathrm{h}$. The membrane fouling was observed by increasing of TMP reached up to 4 psi. This was happened twice at HRT of $04.00 \mathrm{~h}$ after 88 days of operation. The removal of $98 \%$ of colour was indicated that, the treated effluent would be again reusable for the different processes of textile industry. The conductivity, TDS and TP needs further treatment like. Reverse osmosis or nanofiltration. The overall outcomes of this study indicated that synthetic textile wastewater can be effectively treated by the SMBR model and it has been recommended for the treatment of real textile wastewater.

\section{AKNOWLEDGEMENT}

Authors are thankful to Shri. G.H. Raisoni Foundation for giving financial support to this research work. We also thank Director, School of Environmental and Earth Sciences, Kavayitri Bahinabai Chaudhari North Maharashtra University, Jalgaon for providing necessary facilities.

\section{NOMENCLATURE}

SMBR: submerged membrane bioreactor

EC: electric conductivity

HRT: hydraulic retention time

SRT: solid retention time

TDS: total dissolved solids

TSS: total suspended solids

MLSS: mixed liquor suspended solids

MLVSS: mixed liquor volatile suspended solids

COD: chemical oxygen demand

BOD: biochemical oxygen demand

TP: total phosphorus

OLR: organic loading rate

PVDF: polyvinylidene fluoride

TMP: transmembrane pressure

$\mathrm{F} / \mathrm{M}$ ratio: food/microorganisms ratio

\section{REFERENCES}

[1] Bouhadjar, S. I., Deowan, S. A., Galiano, F., Figoli, A., Hoinkis, J., \& Djennad, M. (2016). Performance of commercial membranes in a sidestream and submerged membrane bioreactor for model textile wastewater treatment. Desalination and Water Treatment, 57(12),5275-5285. doi:10.1080/19443994.2015.1022005.

[2] Lubello, C., \& Gori, R. (2004). Membrane bioreactor for advanced textile wastewater treatment and reuse. Water Science and Technology, 50(2), 113-119.

[3] Gozálvez-Zafrilla, J. M., Sanz-Escribano, D., Lora-García, J., \& León Hidalgo, M. C. (2008). Nanofiltration of secondary effluent for wastewater reuse in the textile industry. Desalination, 222(1-3),272-279. doi:10.1016/j.desal.2007.01.173

[4] Nandy, T., Manekar, P., Dhodapkar, R., Pophali, G., \& Devotta, S. (2007). Water conservation through implementation of ultrafiltration and reverse osmosis system with recourse to recycling of effluent in textile industry-A case study. Resources, Conservation and Recycling, 51(1), 64-77. doi:10.1016/j.resconrec.2006.08.004

[5] Sandhya, S., Sarayu, K., \& Swaminathan, K. (2008). Determination of kinetic constants of hybrid textile wastewater treatment system. Bioresource Technology, 99(13), 5793-5797. doi:10.1016/j.biortech.2007.10.011

[6] Badani, Z., Ait-Amar, H., Si-Salah, A., Brik, M., \& Fuchs, W. (2005). Treatment of textile waste water by membrane bioreactor and reuse. Desalination, 185(1-3), 411-417. doi:10.1016/j.desal.2005.03.088

[7] Chen, X., Shen, Z., Zhu, X., Fan, Y., \& Wang, W. (2005). Advanced treatment of textile wastewater for reuse using electrochemical oxidation and membrane filtration. Water SA, 31(1), 127-132. doi:10.4314/wsa.v31i1.5129

[8] Fersi, C., \& Dhahbi, M. (2008). Treatment of textile plant effluent by ultrafiltration and/or nanofiltration for water reuse. Desalination, 222(1-3),263-271 doi:10.1016/j.desal.2007.01.171

[9] Majhi, S., Sharma, Y. C., \& Upadhyay, S. N. (2009). Reverse micelles for the removal of dyes from aqueous solutions. Environmental Technology,30(9),879-884. doi:10.1080/09593330902926489

[10] ElDefrawy, N. M. H., \& Shaalan, H. F. (2007). Integrated membrane solutions for green textile industries. Desalination, 204(1-3 SPEC. ISS.), 241-254. doi:10.1016/j.desal.2006.03.542

[11] Sirianuntapiboon, S., \& Sansak, J. (2008). Treatability studies with granular activated carbon (GAC) and sequencing batch reactor (SBR) system for textile wastewater containing direct dyes. Journal of Hazardous Materials, 159(2-3),404411. doi:10.1016/j.jhazmat.2008.02.031

[12] Khataee, A. R. (2010). Optimization of UVpromoted peroxydisulphate oxidation of C.I. basic blue 3 using response surface methodology. 
International Journal of Research in Advent Technology, Vol.7, No.4, April 2019

E-ISSN: 2321-9637

Available online at www.ijrat.org

Environmental Technology,31(1),73-86. doi:10.1080/09593330903358302

[13] Yigit, N. O., Uzal, N., Koseoglu, H., Harman, I., Yukseler, H., Yetis, U., et al. (2009). Treatment of a denim producing textile industry wastewater using pilot-scale membrane bioreactor. Desalination, 240(1-3), 143-150. doi:10.1016/j.desal.2007.11.071

[14] Brik, M., Schoeberl, P., Chamam, B., Braun, R., \& Fuchs, W. (2006). Advanced treatment of textile wastewater towards reuse using a membrane bioreactor. Process Biochemistry, 41(8), 17511757. doi:10.1016/j.procbio.2006.03.019

[15] Niren, P., \& Jigisha, P. (2011). Textile wastewater treatment using a UF hollow-fibre submerged membrane bioreactor (SMBR). Environmental Technology, 32(11), 1247-1257. doi:10.1080/09593330.2010.534821

[16] Kim, T. H., Lee, Y., Yang, J., Lee, B., Park, C., \& Kim, S. (2004). Decolorization of dye solutions by a membrane bioreactor (MBR) using white-rot fungi. Desalination, 168(1-3), 287-293. doi:10.1016/j.desal.2004.07.011

[17] Mohammed, T. A., Birima, A. H., Noor, M. J. M. M., Muyibi, S. A., \& Idris, A. (2008). Evaluation of using membrane bioreactor for treating municipal wastewater at different operating conditions. Desalination, 221(1-3), 502-510. doi:10.1016/j.desal.2007.02.058

[18] Schoeberl, P., Brik, M., Braun, R., \& Fuchs, W. (2005). Treatment and recycling of textile wastewater - Case study and development of a recycling concept. Desalination, 171(2), 173-183. doi:10.1016/j.desal.2004.02.105

[19] Stephenson, T., Judd, S. J., Jefferson, B., \& Brindle, K. (2003). Membrane Bioreactors for Wastewater Treatment (Japanese). doi:10.1016/bs.coac.2018.02.002

[20] Chang, I.-S., Le Clech, P., Jefferson, B., \& Judd, S. (2002). Membrane Fouling in Membrane Bioreactors for Wastewater Treatment. Journal of Environmental Engineering, 128(11), 1018-1029. doi:10.1061/(ASCE)07339372(2002)128:11(1018)

[21]Fan, F., Zhou, H., \& Husain, H. (2006). Identification of wastewater sludge characteristics to predict critical flux for membrane bioreactor processes. Water Research, 40(2), 205-212. doi:10.1016/j.watres.2005.10.037

[22] Fane, A. (2002). Membrane bioreactors: Design and operational options. Filtration and Separation, 39(5), 26-29. doi:10.1016/S0015-1882(02)801689

[23] Massé, A., Spérandio, M., \& Cabassud, C. (2006). Comparison of sludge characteristics and performance of a submerged membrane bioreactor and an activated sludge process at high solids retention time. Water Research, 40(12), 24052415. doi:10.1016/j.watres.2006.04.015

[24] Ng, H. Y., Tan, T. W., \& Ong, S. L. (2006). Membrane fouling of submerged membrane bioreactors: Impact of mean cell residence time and the contributing factors. Environmental Science and Technology, 40(8), 2706-2713. doi:10.1021/es0516155

[25] Gander, M., Jefferson, B., \& Judd, S. (2000). Aerobic MBRs for domestic wastewater treatment: A review with cost considerations. Separation and Purification Technology, 18(2), 119-130. doi:10.1016/S1383-5866(99)00056-8

[26] García, J. V., Dow, N., Milne, N., Zhang, J., Naidoo, L., Gray, S., \& Duke, M. (2018). Membrane distillation trial on textile wastewater containing surfactants using hydrophobic and hydrophilic-coated polytetrafluoroethylene (PTFE) membranes. Membranes, 8(2). doi:10.3390/membranes 8020031

[27] Huang, R.-R., Hoinkis, J., Hu, Q., \& Koch, F. (2009). Treatment of dyeing wastewater by hollow fiber membrane biological reactor. Desalination and Water Treatment, 11(1-3), 288-293. doi:10.5004/dwt.2009.863

[28] You, S. J., \& Teng, J. Y. (2009). Anaerobic decolorization bacteria for the treatment of azo dye in a sequential anaerobic and aerobic membrane bioreactor. Journal of the Taiwan Institute of Chemical Engineers, 40(5), 500-504. doi:10.1016/j.jtice.2009.01.007

[29] Howell, J. A., Chua, H. C., \& Arnot, T. C. (2004). In situ manipulation of critical flux in a submerged membrane bioreactor using variable aeration rates, and effects of membrane history. Journal of Membrane Science, 242(1-2), 13-19. doi:10.1016/j.memsci.2004.05.013

[30] Deowan, S. A., Galiano, F., Hoinkis, J., Figoli, A., \& Drioli, E. (2013). Submerged Membrane Bioreactor (SMBR) for Treatment of Textile Dye Wastewatertowards Developing Novel MBR Process. APCBEE Procedia, 5, 259-264. doi:10.1016/j.apcbee.2013.05.045

[31] APHA. (2012). Standard Methods for the Examination of Water and Wastewater. 21th ed. American Public Health Association, Washington DC, USA. doi:10.1080/19447013008687143

[32] Saha, P., Hossain, M. Z., Mozumder, M. S. I., Uddin, M. T., Islam, M. A., Hoinkis, J., et al. (2014). MBR technology for textile wastewater treatment: First experience in Bangladesh. Membrane Water Treatment, 5(3), 197-205. doi:10.12989/mwt.2014.5.3.197

[33] Malpei, F., Bonomo, L., \& Rozzi, A. (2003). Feasibility study to upgrade a textile wastewater treatment plant by a hollow fibre membrane 
International Journal of Research in Advent Technology, Vol.7, No.4, April 2019

E-ISSN: 2321-9637

\section{Available online at www.ijrat.org}

bioreactor for effluent reuse. Water Science and Technology, 47(10), 33-39.

[34] Spagni, A., Grilli, S., Casu, S., \& Mattioli, D. (2010). Treatment of a simulated textile wastewater containing the azo-dye reactive orange 16 in an anaerobic-biofilm anoxic-aerobic membrane bioreactor. International Biodeterioration and Biodegradation, 64(7), 676681. doi:10.1016/j.ibiod.2010.08.004

[35] Sun, F., Sun, B., Hu, J., He, Y., \& Wu, W. (2015). Organics and nitrogen removal from textile auxiliaries wastewater with A2O-MBR in a pilotscale. Journal of Hazardous Materials, 286, 416424. doi:10.1016/j.jhazmat.2015.01.031

[36] Awadalla, F. T., Striez, C., \& Lamb, K. (1994). Removal of ammonium and nitrate ions from mine effluents by membrane technology. Separation Science and Technology, 29(4), 483-495. doi:10.1080/01496399408002157

[37] Zheng, Y., Yu, S., Shuai, S., Zhou, Q., Cheng, Q., Liu, M., \& Gao, C. (2013). Color removal and COD reduction of biologically treated textile effluent through submerged filtration using hollow fiber nanofiltration membrane. Desalination, 314, 89-95. doi:10.1016/j.desal.2013.01.004

[38] Chakrabarti, S. (2000): Data mining for hypertext: A tutorial survey. SIGKDD explorations, 1(2), pp. $1-11$. 